\title{
Postoperative nausea and vomiting and opioids in children
}

\author{
Marlies Labugger ${ }^{1 *}$, Alexander Avian², Brigitte Messerer ${ }^{1}$, Andreas Sandner-Kiesling ${ }^{1}$ \\ From Safety in hospitals: from strategy to implementation Annual Scientific Meeting 2015 \\ Graz, Austria. 29-30 September 2015
}

\begin{abstract}
Background
We developed and implemented an interdisciplinary pain concept to assess and prevent pain as well as therapyrelated side effects with the objective of outcome improvement. Each pain management starts with profound preoperative information concerning the expected postoperative pain and what can be done to prevent it. For acute pain therapy a regular basic medication with non-opioids and an analgesic on demand (usually opioids) for the management of breakthrough pain of $\geq 4$ is provided postoperatively [1]. There are several studies and risk scores concerning postoperative nausea and vomiting (PONV) related to opioid-treatment in adults [2-6]. We performed a study about this topic in children.
\end{abstract}

\section{Material and methods}

After approval of the institutional ethics committee and after receiving informed consent from parents and children, we conducted a prospective observational study, including 240 children, mean age $14.7 \pm 1.9$ years (range: 11 to 18 years) ( $43 \%$ female) within the first 48 hours after an operation. We evaluated sex, age, BMI, duration of operation, ASA-state and medication during surgery, in the recovery room and on ward. Study participants received a survey about the occurrence of nausea or vomiting and their pain intensity.

\section{Results}

With one exception, opioids were always applied during surgery. Out of the 240 patients, 110 (45.8\%) received an opioid in the recovery room and $50(20.8 \%)$ in the first 48 hours on the ward. Opioids administered during surgery or in the recovery room had no influence on

\footnotetext{
* Correspondence: marlies.labugger@stud.medunigraz.at

'Department of Anesthesiology and Intensive Care Medicine, Medical University of Graz, Austria

Full list of author information is available at the end of the article
}

nausea on the generalward. In contrast the use of opioids on the ward increased the number of patients suffering from nausea compared to patients receiving no opioid ( $46 \%$ vs. $29 \% ; p=0,022)$. Comparable results are observed for vomiting ( $24 \%$ vs. $13 \%$; $\mathrm{p}=.045)$. Overall 51 patients $(21 \%)$ suffered from pain at rest $\geq 4$. Increased pain at rest elevated the incidence of nausea ( $\mathrm{p}=.005)$, but not of vomiting $(\mathrm{p}=.551)$. While $49 \%$ of patients with pain at rest $\geq 4$ suffered from nausea only $28 \%$ of patients with pain at rest $<4$ suffered from nausea.

\section{Conclusions}

Our study confirms the results from adults, that the postoperative use of opioids on the ward, but not in the recovery room, increased the incidence of PONV. Higher pain levels at rest correlated with an increased incidence of postoperative nausea, but not vomiting. Our results shall encourage an increased awareness about the high incidence of PONV postoperatively, especially after its

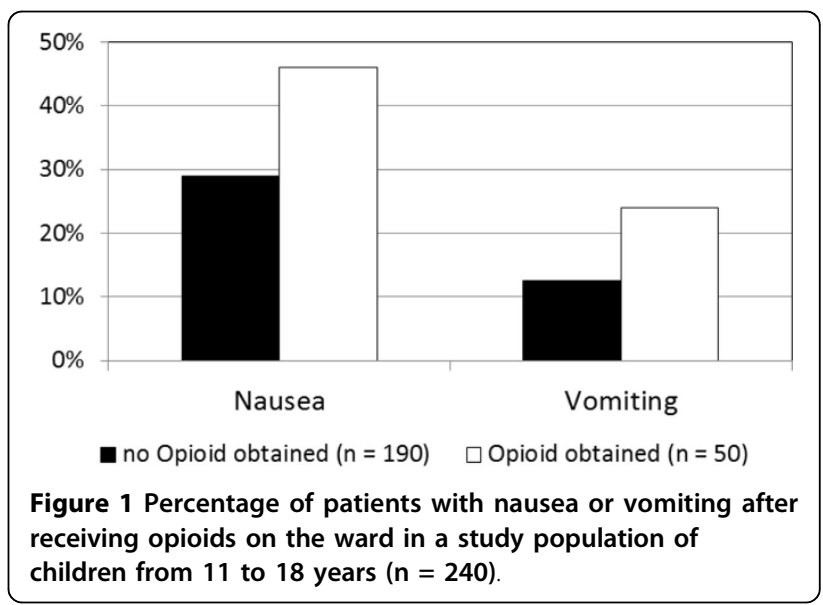


application on the ward. Additionally, they emphasize more preventive use of antiemetics.

\section{Authors' details}

${ }^{1}$ Department of Anesthesiology and Intensive Care Medicine, Medical University of Graz, Austria. ${ }^{2}$ Institute for Medical Informatics, Statistic and

Documentation, Medical University of Graz, Austria.

Published: 30 October 2015

\section{References}

1. Messerer B, Gutmann A, Weinberg A, Sandner-Kiesling A: Implementation of a standardized pain management in a pediatric surgery unit. Pediatr Surg Int 2010, 26(9):879-89.

2. Rusch D, Eberhart LH, Wallenborn J, Kranke P: Nausea and vomiting after surgery under general anesthesia: an evidence-based review concerning risk assessment, prevention, and treatment. Deutsches Arzteblatt international 2010, 107(42):733-41.

3. Apfel CC, Kranke P, Piper S, Rüsch D, Kerger H, Steinfath $M$, et al: Übelkeit und Erbrechen in der postoperativen Phase. Anaesthesist 2007, 56(11):1170-80.

4. Apfel CC, Korttila K, Abdalla M, et al: A Factorial Trial of Six Interventions for the Prevention of Postoperative Nausea and Vomiting. New England Journal of Medicine 2004, 350:24.

5. Gan TJ: Risk factors for postoperative nausea and vomiting. Anesth Analg 2006, 102(6):1884-98.

6. Eberhart LH, Geldner G, Kranke P, Morin AM, Schäuffelen A, Treiber H, et al: The development and validation of a risk score to predict the probability of postoperative vomiting in pediatric patients. Anesth Analg 2004, 99(6):1630-7.

doi:10.1186/2056-5917-1-S1-A5

Cite this article as: Labugger et al:: Postoperative nausea and vomiting and opioids in children. Safety in Health 2015 1(Suppl 1):A5.

\section{Submit your next manuscript to BioMed Central} and take full advantage of:

- Convenient online submission

- Thorough peer review

- No space constraints or color figure charges

- Immediate publication on acceptance

- Inclusion in PubMed, CAS, Scopus and Google Scholar

- Research which is freely available for redistribution

Submit your manuscript at www.biomedcentral.com/submit
C Biomed Central 